\title{
A Comparative Study on the RFS Program of Korea with the US and UK
}

\author{
Jung-Yull Shin ${ }^{1,2}$, Gun-Woo Kim ${ }^{1,2}$, Janet S. Zepernick ${ }^{3}$ (i) and Kyu-Young Kang 1,4,* \\ 1 Department of Renewable Energy Engineering, Graduate School, Dongguk University-Seoul, 30 Pildong-ro 1-gil, \\ Jung-gu, Seoul 04620, Korea; nepassion@energy.or.kr (J.-Y.S.); gw@energy.or.kr (G.-W.K.) \\ 2 Korea Energy Agency, 388 Poeundae-ro, Suji-gu, Yongin 16842, Korea \\ 3 Department of English \& Modern Languages, College of Arts and Sciences, Pittsburg State University, \\ 1701 South Broadway Street, Pittsburg, KS 66762, USA; jzepernick@pittstate.edu \\ 4 Department of Biological and Environmental Science, College of Life Science and Biotechnology, \\ Dongguk University-Seoul, 32 Dongguk-ro, Ilsandong-gu, Goyang 10326, Korea \\ * Correspondence: kykang@dongguk.edu; Tel.: +82-31-961-5125
}

Received: 18 October 2018; Accepted: 30 November 2018; Published: 5 December 2018

check for updates

\begin{abstract}
In 2016, the global environmental impact of greenhouse gas (GHG) emissions was 49.3 gigatons $\mathrm{CO}_{2}$ equivalent. Worldwide, the transportation sector is responsible for $14 \%$ of GHG. Electric vehicles (EV) powered by less-polluting energy sources are one way to reduce the environmental impact of the transportation sector, but immediate transportation demands cannot be met by existing EV technology. Use of less polluting biofuel in place of petroleum-based gasoline or diesel fuel to power the existing transportation fleet is a widely accepted transitional solution, including in the Republic of Korea. The purpose of this research is to investigate approaches to biofuels in the US and the UK in order to evaluate Korea's current energy policies related to use of biofuels and to make recommendations for strengthening Korea's energy policy. This article addresses only policies for use of biodiesel rather than ethanol (widely used in the US) because ethanol is not used in Korea. This research shows that Korea calculates GHG using the principle that biofuel is carbon neutral, but energy policies in the US and the UK treat biofuel as not entirely carbon neutral. Korea should examine how to calculate GHG from biodiesel according to the standard set by the UK in order to work toward a more environmentally sustainable energy policy.
\end{abstract}

Keywords: RFS (Renewable Fuel Standards); renewable energy; biodiesel; $\mathrm{CO}_{2}$; GHG; sustainability; carbon neutral

\section{Introduction}

\subsection{Research Objective}

The purpose of this paper is to identify the shortcomings of Korea's biodiesel program, including its Renewable Fuel Standard (RFS), and to propose modifications to the program in order to improve the environmental sustainability of biodiesel in Korea. The seventh largest GHG emitting country, Korea is implementing a biodiesel program to improve the sustainability of its energy supply by increasing biodiesel use in the transportation sector [1]. However, while Korea calculates GHG emissions using the principle that biofuel is carbon neutral, energy policies in the US and the UK treat biofuel as not entirely carbon neutral. These countries include GHG emissions of specific biofuel sources and production processes in calculating total GHG emissions for biofuel from various sources.

Recently, the EU publicly announced that it would ban the import of palm oil, one of the biggest sources of GHG emissions among biofuel feedstocks, for use in biofuel as part of the EU's plan to increase biofuel use while keeping environmental sustainability in view [2]. This is the hottest issue 
in the biofuel market because the ban on palm oil is regarded not just as the ban of a feedstock in the EU, but also as a trade war between the EU and Indonesia, the world's largest exporter of palm oil. The EU's ban on palm oil is also part of a larger global trend toward greater environmental sustainability in the world's energy supply, a trend that may have important implications for energy policy in Korea. The question of the carbon neutrality of biofuels was raised at the establishment of Korea's RFS program in 2013 and has been acknowledged by the Korean government and related agencies. However, the RFS program has not been modified to address this issue.

The purpose of this research, therefore, is to investigate approaches to the use of biofuels in the US and the UK, to evaluate Korea's current energy policies related to biofuels in comparison to the policies of the US and UK, and to make recommendations for strengthening Korea's energy policy. This article only addresses policies related to biodiesel rather than ethanol (widely used in the US) because ethanol is not used in Korea. The paper is structured as follows. Section 1 describes policies related to biodiesel in the US, EU, UK, and Korea. Section 2 explains data and methods of analysis used to evaluate the sustainability of biofuel usage. Section 3 shows the result of that analysis, specifically with respect to how GHG emissions in Korea would be affected by following the standard set by the UK. Section 4 discusses the implications for Korea's RFS, and Section 5 summarizes the article's recommendations.

\subsection{Biofuel in the World Energy Supply}

As of 2018, approximately 3\% of world road transport fuel is provided by ethanol, biodiesel, and other biofuels. Figure 1 shows the share of worldwide energy provided by traditional, modern, and non-biomass sources in 2015, when about $2.6 \%$ of fuel for the world transportation sector, including aviation, came from biofuel [3]. As shown in Figure 2, an estimated $72 \%$ of biofuel production was ethanol, $23 \%$ biodiesel, and $4 \%$ was hydrotreated vegetable oil (HVO).

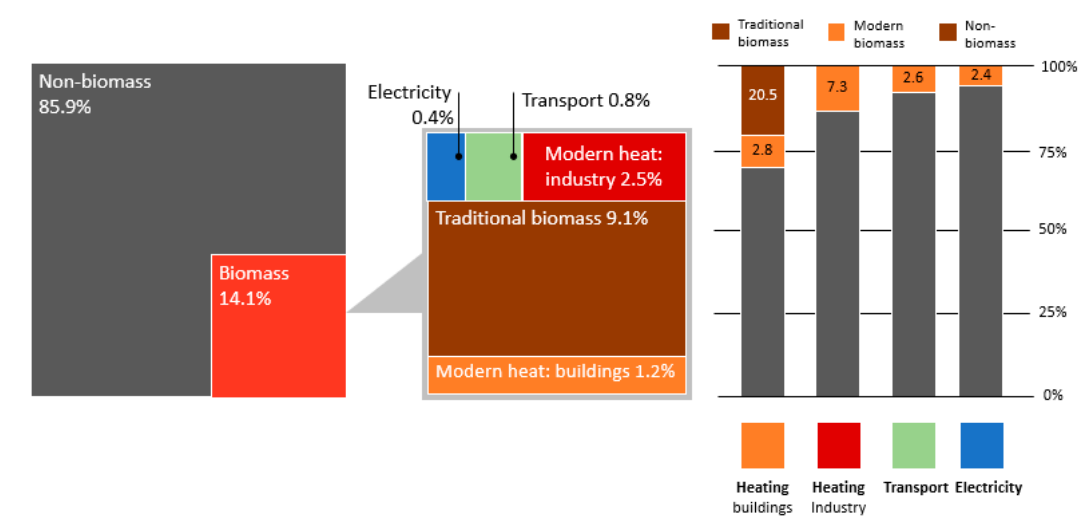

Figure 1. Shares of biomass in total final energy consumption and in final energy consumption by the end-use sector 2015 [3].

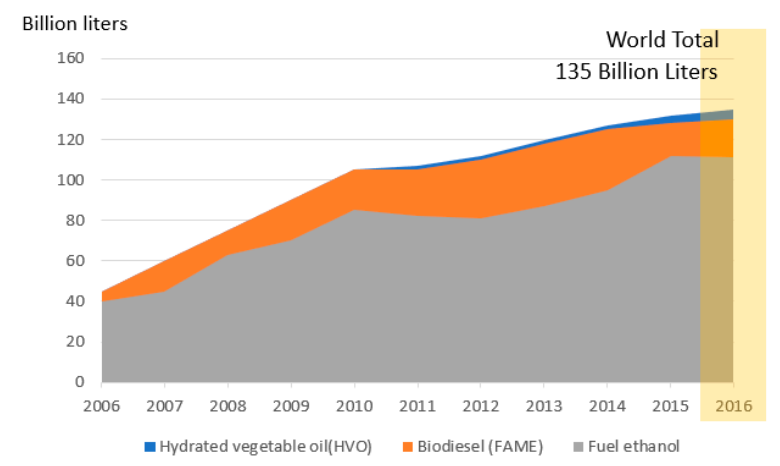

Figure 2. Global trends in ethanol, biodiesel, fatty acid methyl ester (FAME), and HVO production, 2006-2016 [3]. 
The International Energy Agency's (IEA) 450 Scenario sets out an energy pathway consistent with the goal of limiting the global increase in temperature to $2{ }^{\circ} \mathrm{C}$ by limiting concentrations of GHG in the atmosphere to around 450 parts per million of $\mathrm{CO}_{2}$ eq. According to the 450 Scenario, biofuel is expected to meet about $17 \%$ of the world transportation sector demand for fuel, including in the aviation sector, through the development and deployment of advanced biofuels coming from waste, algae, and cellulosic feedstocks. As shown in Figure 3, the 450 Scenario anticipates that electric vehicles (EV) will increasingly replace light duty combustion engine vehicles and that biofuel will replace refined petroleum products, namely gasoline, diesel, and kerosene [4].
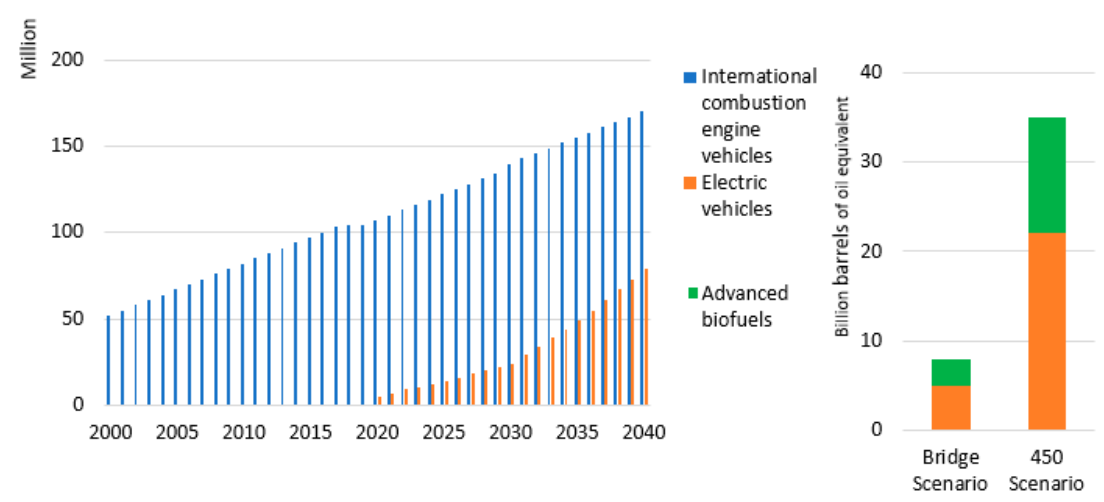

Figure 3. Global sales of light-duty passenger and commercial vehicles by type in the 450 Scenario (left) and global cumulative oil savings resulting from use of EVs and advanced biofuels, 2015-2040.

\subsubsection{Biofuel in the US}

As shown in Figure 4, use of biofuel in the US has expanded dramatically over the past decade in response to the RFS program, passed by Congress in 2007, which imposed obligations on the part of oil refineries and importers to blend biofuel with conventional fuels [5]. Since 2007, the US has been the largest ethanol-producing country in the world, accounting for 15,800 million gallons in 2017 [6].

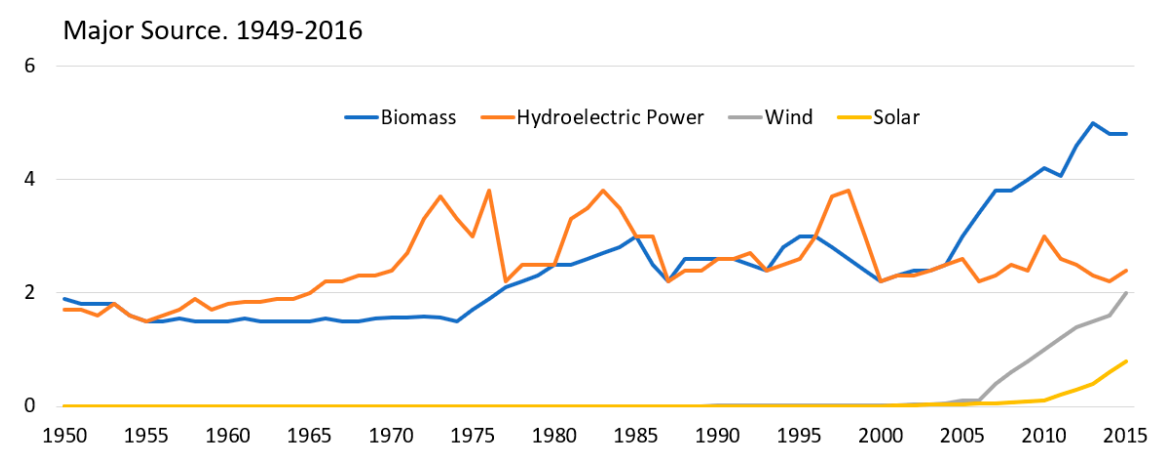

Figure 4. Renewable consumption, quadrillion Btu [7].

Following aggressively expanded production of biofuel in the 2000s, two studies published in 2008 argued that in spite of biofuel's many advantages, use of croplands for biofuels increases GHG when emissions from land use change (LUC) are factored into the equation [8,9]. These studies had a significant impact on the standards for calculating the carbon savings of biofuels over petroleum-based fuels, resulting in the adoption of "lifecycle" based standards that consider the carbon cost of a feedstock throughout its lifecycle, as described below.

An increase in the consumption of biofuel feedstocks leads inevitably to an increase in land used for agriculture in one of two ways: directly, when new cropland is created for the production of biofuel feedstocks, resulting in direct land use change (DLUC), or indirectly, when existing cropland is used for biofuel feedstock production, forcing food, feed, and materials to be produced on new 
cropland elsewhere, resulting in indirect land use change (ILUC). The two largest biologically active stores of terrestrial carbon are soils and plant biomass, which have 2.7 times more carbon than the atmosphere [8]. Searchinger et al. argued that diverting land from its existing uses led to the sacrifice of carbon sequestration and that GHG calculations had ignored land use change (LUC) emissions [9]. These reports argued that biofuels from waste products, municipal waste, crop-waste, and fall grass harvests from reserved lands could reduce GHG emissions more than biofuels from specially grown feedstocks [9].

\subsubsection{Biofuel in the EU}

Before discussing the state of biofuel in the UK, it is necessary to discuss the EU's policies because most of the UK's renewable energy policy is closely related to the EU's Renewable Energy Directive (RED). However, following Brexit, the UK's current stance on the RED is unclear, and the UK has not announced its position with respect to the EU's energy and climate targets [10].

Like the US, the EU is working to increase the proportion of biofuel in the transportation fuel market; however, concerns about ILUC and DLUC in the production of biofuel represent a significant dilemma. In addition to the impact of LUC on GHG emissions, the possibility also exists that diverting agricultural land to the production of feedstocks for biofuel will interfere with the production of food crops for human consumption. To address this concern, the EU's RED (2009/28/EC) specifically ordered the European Commission to develop a methodology for accounting for the effect ILUC. However, ILUC is connected with other factors in agricultural markets at local levels as well as global ones, so its impacts cannot easily be determined [11].

In response to concerns about the environmental impact of biodiesel feedstocks, in January 2018, the European Parliament proposed a ban on the use of vegetable oils like palm oil to produce biodiesel after 2020, which would represent a significant new direction in the EU's use of biofuels [12]. In 2016 and 2017, the EU was one of the largest palm oil importers in the world, importing about seven million tons. Consequently, the EU's ban on biodiesel made from palm oil will also affect the economies of the EU's primary suppliers of palm oil, Indonesia and Malaysia, whose economies depend on palm oil export [13]. The EU accounts for approximately 10\% of Indonesia's total palm oil exports [14]. While palm oil may not be an inherently environmentally unsustainable feedstock, use of palm oil as a foundation for carbon mitigation through biodiesel runs the risk of merely transferring the carbon cost from the consuming country to the producing country without fundamentally altering the overall GHG profile [15].

\subsubsection{Biofuel in the UK}

In 2003, the UK introduced a climate change policy designed to reduce $\mathrm{CO}_{2}$ emissions $20 \%$ by 2010 and $60 \%$ by 2050 , with increased use of biofuel as one measure to achieve the target. This program came into force in 2008 in the form of the Renewable Transport Fuel Obligation (RTFO) [16]. The RTFO has been one of the UK's main programs to mitigate GHG emissions from the transport sector, and in 2011, it was amended to follow the transport elements of the EU's RED. The RTFO program requires biofuel suppliers to meet its sustainability criteria, including blend ratio, to receive Renewable Transport Fuel Certificates (RTFC). In 2013 the program was expanded to include new renewable fuels [17].

\subsubsection{Biofuel in Korea}

Korea's RFS, first introduced as a pilot program in 2002, is intended to increase the use of fuel from renewable energy sources in the transportation sector as part of a national effort to reduce GHG emissions. One notable finding of the pilot program was the problem of fuel filters clogging at low temperatures when the biofuel blend ratio was too high. Based on this finding, $0.5 \%$ biofuel (B0.5) was established as the minimum blend ratio for biodiesel supplied to the transportation market beginning in 2006, and a tax exemption was enacted to promote use of biodiesel. The RFS program became a regulatory policy in 2012, with a blend ratio of 2\% [18]. The current RFS was introduced in 2015 in conjunction with Korea's Intended Nationally Determined Contribution (INDC) plan, which also 
identified mitigation measures in various sectors [19]. In the transport sector, the INDC continues to increase environment-friendly public transportation and strengthens low-carbon standards. Overall, the most effective way to mitigate GHG directly is to raise the blend ratio of biofuel. However, at this time, Korea's primary feedstocks for biodiesel are imported palm oil and used cooking oil (UCO). As the blend ratio increases, the share of imported feedstock increases [18].

In January 2018, the Korean government announced an increase in the blend ratio from $2.5 \%$ biofuel (B2.5) to 3\% biofuel (B3) beginning in 2018 [20]. In response, some of the nation's media argued that this position was in opposition to global trends, especially the EU's decision to ban biodiesel from palm oil, and pointed out a lack of sustainability of biodiesel in Korea [21]. In addition, it was argued that this policy would increase the cost of fuel in the transportation sector [22-24].

Korea was the first nation in Asia to introduce a standard for renewable fuel [18]. However, Korea's RFS does not have a long-term master plan and has a relatively lower blend ratio than other counties' energy policies. For example, the current blend ratio for biodiesel in Korea is B3, while in Thailand, the current mandatory blend ratio is B7. Additionally, unlike the US and the UK, Korea does not have sustainability and carbon-saving criteria for feedstocks [25]. The transportation sector represents about $25 \%$ of total energy consumption in Korea, which means that limitations in Korea's approach to sustainability in the transport sector reduce the overall effectiveness of Korea's GHG mitigation plan.

\subsection{Comparison of RFS Program by Country}

Although Korea's RFS program has superficial similarities to the US's RFS program and the UK's RTFO, the differences are significant. As Table 1 shows, the UK and US programs include sustainability criteria, cover multiple renewable fuels, set long term targets, and include mechanisms by which obligated parties can buy and trade compliance credits. Korea's RFS program includes none of these elements. This analysis focuses specifically on sustainability criteria.

Table 1. Comparison of renewable fuel programs in Korea, the US, and the UK [26-28].

\begin{tabular}{|c|c|c|c|}
\hline & Korea & US & UK \\
\hline Program & RFS & RFS & RTFO \\
\hline Implement agency & KEA, K-Petro & EPA & DfT \\
\hline Start year & 2015 & $\begin{array}{l}\text { RFS 1: 2007.9 2010.11 } \\
\text { RFS 2: 2010.12 2022 }\end{array}$ & 2008 \\
\hline Volume target & $\begin{array}{l}\text { Blending 3\% biodiesel } \\
\text { with conventional diesel } \\
(2018 \sim 2020)\end{array}$ & $\begin{array}{l}36 \text { billion gallons of renewable fuel } \\
\text { by } 2022\end{array}$ & $\begin{array}{l}\text { Biofuel volume } \\
-\quad 2018: 7.3 \%, 2020: 9.8 \% \text {, } \\
\text { 2032: } 12.4 \%\end{array}$ \\
\hline $\begin{array}{l}\text { Renewable fuel } \\
\text { under the RFS }\end{array}$ & Biodiesel & $\begin{array}{l}\text { Biomass-based diesel } \\
\text { Cellulosic and } \\
\text { Advanced biofuel } \\
\text { Total renewable fuel }\end{array}$ & $\begin{array}{l}\text { Biofuel, partial biofuels, } \\
\text { renewable fuels of } \\
\text { non-biological origin } \\
\text { (RFNBOs) and fuels that are } \\
\text { part RFNBO, part non-RFNBO }\end{array}$ \\
\hline Obligated parties & $\begin{array}{l}\text { Refineries or imports of } \\
\text { diesel fuel }\end{array}$ & $\begin{array}{l}\text { Refineries or imports of gasoline or } \\
\text { diesel fuel }\end{array}$ & $\begin{array}{l}\text { Suppliers of transport and } \\
\text { nonroad mobile machinery fuel }\end{array}$ \\
\hline Compliance & $\begin{array}{l}\text { Blending biodiesel into } \\
\text { transportation fuel }\end{array}$ & $\begin{array}{l}\text { Blending renewable fuels into } \\
\text { transportation fuel obtaining credits, } \\
\text { Renewable Identification Numbers } \\
\text { (RINs) to meet an EPA-specific } \\
\text { renewable volume obligation }\end{array}$ & $\begin{array}{l}\text { Mandatory sustainability } \\
\text { criteria have to be met for } \\
\text { biofuels to be issued with } \\
\text { Renewable Transport Fuel } \\
\text { Certificates (RTFCs) and count } \\
\text { towards suppliers' obligations }\end{array}$ \\
\hline $\begin{array}{l}\text { Fuel pathway } \\
\text { (Sustainability) }\end{array}$ & $\begin{array}{l}\text { All of the biodiesels } \\
\text { blended are granted to } \\
\text { be } 100 \% \text { GHG reduction, } \\
\text { carbon neutral }\end{array}$ & $\begin{array}{l}\text { Lifecycle GHG reduction (as compared } \\
\text { to a } 2005 \text { petroleum baseline) } \\
\text { - } \\
\text { - } \\
\text { Biomass based diesel: } 50 \% \\
\text { - } \\
\text { - } \\
\text { Advallulosic biofuel: } 60 \% \\
\text { Total renewable fuel: } 20 \%\end{array}$ & $\begin{array}{l}\text { At least } 60 \% \text { lower carbon } \\
\text { footprint than their fossil fuel } \\
\text { alternatives GHG, } \\
83.8 \text { gCO2eq/MJ }\end{array}$ \\
\hline
\end{tabular}




\section{Data and Methods}

This analysis examines the role of sustainability criteria in renewable fuel programs to ensure that biofuel standards are used in ways that guarantee real carbon savings and protect biodiversity with the goal of evaluating Korea's RFS program [29]. The RFS program of the US and the RTFO program of the UK are used as the basis for comparison for the following reasons. When Korea's renewable fuels program was first developed, the US's RFS served as the benchmark for several key aspects of what became Korea's RFS, including program structure, blending plans, obligated parties, and compliance [30]. Due to the established similarities between the two programs, comparison to the US's RFS is informative. At the same time, however, the UK serves as a much better model for Korea's energy environment with respect to a lack of abundant domestic energy sources and similarity of feedstocks for biodiesel, including UCO, tallow, palm oil, and soybean oil [31]. In order to arrive at a more accurate measure of the GHG reduction associated with Korea's RFS, the carbon savings and sustainability of specific fuel types will also be considered in evaluating Korea's RFS program.

\subsection{Sustainability of Biodiesel in the US}

The US government is trying to expand the nation's renewable fuel sector by reducing both GHG and reliance on imported oil. The State and Alternative Fuel Provider Fleet Program of the Department of Energy and the RFS of the Environmental Protection Agency (EPA) are the main programs to reduce GHG; both require covered fleets to use alternative fuels, including biofuels [32]. However, these programs not only require fleets to use biofuels but also mandate the use of biofuels that meet their sustainability criteria. In 2010, the EPA established new fuel pathways to qualify for RFS, consisting of a specific combination of three components: Feedstock, production process, and fuel type. Assessment of lifecycle GHG emissions is necessary to determine which fuel pathways can qualify [33]. The EPA's lifecycle GHG analyses take into account all of the energy used during the entire feedstock-to-fuel lifecycle from planting to final processing, as well as DLUC, ILUC, and emissions from storage and handling of the refined fuel (see Figure 5).

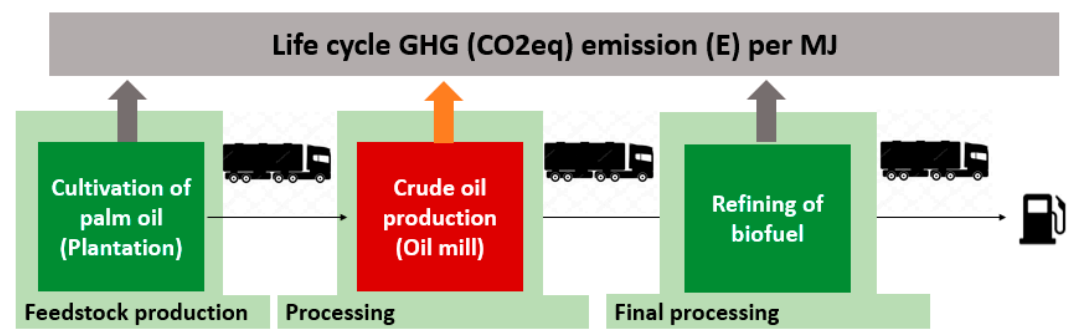

Figure 5. Life cycle greenhouse gas emissions (GHG) of palm oil-based biofuel [34].

To qualify under RFS, fuels must reduce GHG emissions compared to a 2005 petroleum baseline. As shown in Figure 6, the EPA has approved fuel pathways under the RFS program for renewable, advanced, biodiesel, and cellulosic fuels. As Figure 6 shows, advanced and biodiesel fuels must achieve a GHG reduction of 50\% compared to petroleum-based fuels in order to qualify.
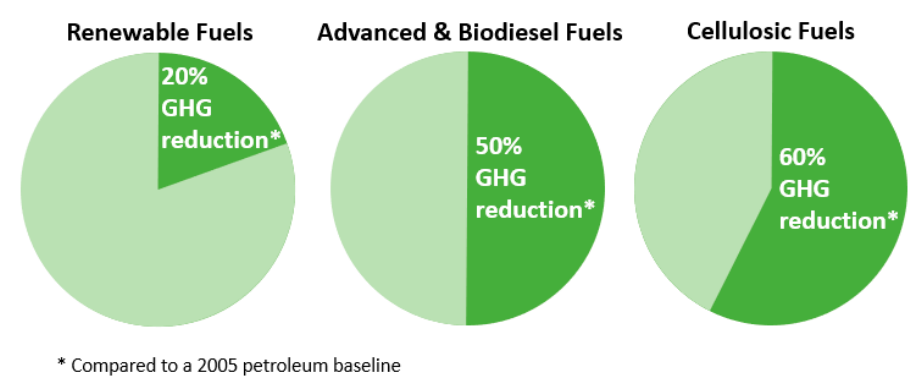

Figure 6. Lifecycle GHG emissions [35]. 
Table 2 shows the lifecycle analysis of GHG resulting from various feedstocks [36]. The EPA's analysis found that biodiesel and renewable diesel produced from palm oil have estimated lifecycle GHG emission reductions of $17 \%$ and $11 \%$, respectively, compared to the baseline petroleum diesel fuel they replace. These biofuels, therefore, fail to meet the minimum GHG emissions reduction threshold of $50 \%$ set by the Energy Independence and Security Act (EISA) for renewable fuel made in facilities constructed after December 19, 2007 [37,38].

Table 2. Lifecycle analysis GHG results for select pathways ( $\left.\mathrm{kg} \mathrm{CO}_{2} \mathrm{eq} / \mathrm{mmBtu}\right)$ [36].

\begin{tabular}{|c|c|c|c|c|c|c|c|c|}
\hline Feedstock & Production Process & $\begin{array}{c}\text { Ag. } \\
\text { Impact }\end{array}$ & LUC & $\begin{array}{l}\text { Feedstock } \\
\text { Transport }\end{array}$ & $\begin{array}{c}\text { Fuel } \\
\text { Production }\end{array}$ & $\begin{array}{l}\text { Fuel Dist. } \\
\text { \& Use }\end{array}$ & $\begin{array}{c}\text { Net } \\
\text { Emissions }\end{array}$ & $\stackrel{\%}{\%}$ Reduction \\
\hline \multirow{2}{*}{ Algal oil } & $\begin{array}{l}\text { Transesterification } \\
\text { (Open pond, mid) }\end{array}$ & 0.0 & 0.0 & 0.0 & 31.5 & 1.5 & 33.0 & $66 \%$ \\
\hline & $\begin{array}{l}\text { Transesterification } \\
\text { (PBR, mid) }\end{array}$ & 0.0 & 0.0 & 0.0 & 26.3 & 1.5 & 27.8 & $71 \%$ \\
\hline \multirow{2}{*}{$\begin{array}{l}\text { Canola oil } \\
\text { Cellulose from } \\
\text { corn stover }\end{array}$} & Transesterification & 8.2 & 33.9 & 1.6 & 2.9 & 1.5 & 48.1 & $50 \%$ \\
\hline & Fischer-Tropsch process & 11.6 & -11.2 & 1.2 & 5.4 & 2.0 & 9.0 & $91 \%$ \\
\hline \multirow{2}{*}{ Palm oil } & Transesterification & 4.8 & 46.1 & 1.3 & 25.1 & 3.4 & 80.7 & $17 \%$ \\
\hline & Hydrotreating & 4.8 & 46.8 & 2.0 & 30.9 & 2.2 & 86.7 & $11 \%$ \\
\hline Soy bean oil & Transesterification & -8.8 & 33.6 & 2.7 & 13.2 & 1.5 & 42.2 & $57 \%$ \\
\hline Switch-grass & Fischer-Tropsch process & 6.5 & 13.1 & 1.6 & 5.4 & 2.0 & 28.6 & $71 \%$ \\
\hline Yellow grease & Transesterification & 0.0 & 0.0 & 2.7 & 9.6 & 1.5 & 13.8 & $86 \%$ \\
\hline Petroleum & Refining & 0.0 & 0.0 & 0.0 & 18.0 & 79.0 & 97.0 & $0 \%$ \\
\hline
\end{tabular}

Analysis by the EPA highlights a number of key factors that contribute to the lifecycle emissions estimates for biofuels based on palm oil. For example, a process of palm oil production causes wastewater effluent that creates methane $\left(\mathrm{CH}_{4}\right)$, a GHG with a high global warming potential. Expanding the expected palm plantations onto land having carbon-rich peat soils is another important factor, as destruction of carbon-rich soils causes greater emissions of GHGs to the atmosphere [37].

Figure 7, above, shows the lifecycle GHG of palm oil-based biodiesel, as calculated using GREET 2017. Palm oil-based biodiesel's GHG emission reduction from the GREET Excel version shown in Table 3 below is approximately $24.2 \mathrm{~kg} \mathrm{CO} 2 \mathrm{eq} / \mathrm{mmBtu}(=10,723+13,468$, the bottom line of Table 3$)$, in which LUC was not included. If the LUC $46.1 \mathrm{~kg} \mathrm{CO} 2 \mathrm{eq} / \mathrm{mmBtu}$ from Table 2 is included, the total GHG will be about $70.3 \mathrm{~kg} \mathrm{CO} 2 \mathrm{eq} / \mathrm{mmBtu}$. This also cannot meet the minimum GHG emission reduction threshold of $50 \%$. GREET does not include LUC due to controversy on how to calculate it.

According to the Argonne National Laboratory, the value $24.2 \mathrm{~kg} \mathrm{CO}_{2} \mathrm{eq} / \mathrm{mmBtu}$ for palm oil-based biodiesel's GHG emission is based on the assumption that the $\mathrm{CH}_{4}$ from palm oil mill effluent is captured. However, due to the high capture cost, some $\mathrm{CH}_{4}$ is not collected and is instead discharged into the environment from production sites. Therefore, $24.2 \mathrm{~kg} \mathrm{CO}$ eq $/ \mathrm{mmBtu}$ is the minimum value, and palm oil-based biodiesel's GHG emission value would increase when uncaptured $\mathrm{CH}_{4}$ and $\mathrm{LUC}$ are considered.

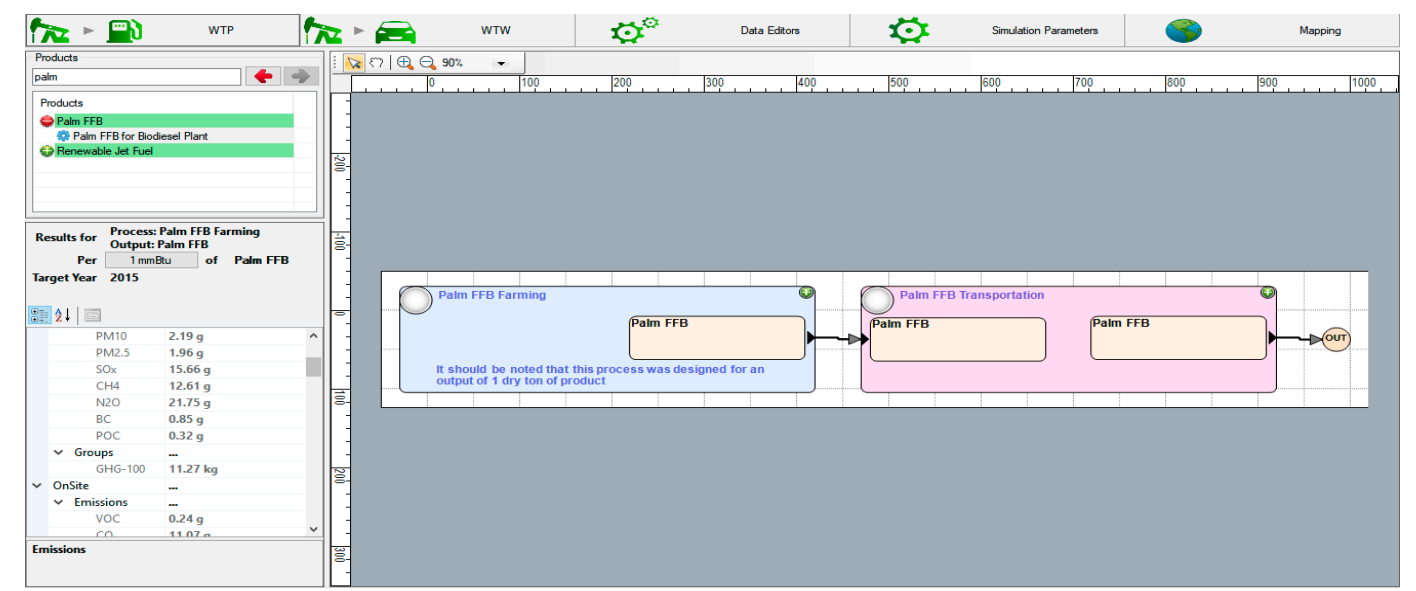

Figure 7. Palm fresh fruit bunches (FFB) lifecycle GHG from GREET 2017 [39]. 
Table 3. Palm oil-based biodiesel emissions ( $\mathrm{g} \mathrm{CO}_{2} \mathrm{eq} / \mathrm{mmBtu}$ ).

\begin{tabular}{ccc}
\hline Emissions & Feedstock & Fuel \\
\hline Loss factor & & 1.000 \\
Unit & per mmBtu & per mmBtu \\
Total energy & 73,005 & 243,951 \\
Fossil fuels & 72,341 & 184,803 \\
Coal & 1,802 & 10,100 \\
Natural gas & 43,444 & 127,123 \\
Petroleum & 27,095 & 47,579 \\
Water consumption & 3.575 & 4.651 \\
VOC & 5.904 & 5.430 \\
$\mathrm{CO}$ & 12.704 & 11.621 \\
$\mathrm{NOx}$ & 33.699 & 68.841 \\
$\mathrm{PM} 10$ & 2.004 & 5.230 \\
$\mathrm{PM} 2.5$ & 1.754 & 4.664 \\
$\mathrm{SOx}$ & 14.471 & 39.803 \\
$\mathrm{BC}$ & 0.705 & 0.802 \\
$\mathrm{OC}$ & 0.302 & 1.757 \\
$\mathrm{CH}$ & 12.373 & 29.676 \\
$\mathrm{~N}_{2} \mathrm{O}$ & 19.659 & 0.170 \\
$\mathrm{CO}$ & 5,104 & 12,498 \\
2 & 5,143 & 12,533 \\
$\mathrm{GHGs}$ & 10,723 & 13,468 \\
\hline
\end{tabular}

\subsection{Sustainability of Biodiesel in the UK}

As mentioned earlier, the EU, including the UK, faces the dilemma of how to expand the role of biofuel as part of their overall energy portfolio while also considering the sustainability of feedstock obtained from land with a high biodiversity value. As a result of this issue, the EU keeps tightening the rules for use of biofuel, including the recent ban of palm oil. While the UK has not officially announced its position on the Indonesian palm oil trade dispute [40], recently, private companies in the UK have moved in advance to ban palm oil. For example, Iceland Foods, a major UK grocery store chain, has announced that it would stop using palm oil in its own-brand food products [41], and despite the lack of a clear official stance on palm oil, since 2015, no biodiesel based on palm oil has been consumed in the UK [42].

The UK's Renewables Obligation (RO) and the RTFO are based on the EU's RED, which establishes an overall policy for the production and promotion of energy from renewable sources in the EU. Under the RED, operators using bioliquids in the EU, as well as the in the UK, must meet specified carbon intensity (CI) sustainability criteria to be eligible for support under national schemes [43,44].

As shown in Table 4, according to the RO sustainability criteria, beginning 1 January2018, the percentage saving required against the fossil fuel comparator will be determined by whether the bioliquid was produced in a facility that began bioliquid production before 1 January 2017. If so, the saving required against the fossil fuel comparator will be $50 \%$. If not, then the saving required will be $60 \%$ [43].

Table 4. GHG thresholds for bioliquids [43].

\begin{tabular}{ccccc}
\hline & Before & 1 January & \multicolumn{2}{c}{ On or after 1 January 2018 } \\
\cline { 3 - 5 } & 1 January 2017 & $\sim 31$ December 2017 & $\begin{array}{c}\text { For bioliquids produced } \\
\text { in an installation that } \\
\text { started producing } \\
\text { bioliquid before } \\
\text { 1 January 2017 }\end{array}$ & $\begin{array}{c}\text { For bioliquids not } \\
\text { produced in an installation } \\
\text { that started producing } \\
\text { bioliquid before } \\
\text { 1 January 2017 }\end{array}$ \\
\hline $\begin{array}{c}\text { GHG emission } \\
\text { threshold }\end{array}$ & $35 \%$ & $50 \%$ & $50 \%$ & $60 \%$ \\
\hline
\end{tabular}

As the RED's Directive 2009/28/EC for biofuels describes, the fossil fuel comparator should be the latest available actual average emissions from the fossil part of petrol and diesel consumed in the 
community, as reported under Directive 98/70/EC. If no such data is available, the value used should be $83.8 \mathrm{~g} \mathrm{CO}_{2}$ eq/MJ [44]. The RTFO guidance also provides the same fossil fuel comparator value.

The RTFO guidance, as shown in Table 5, provides each biodiesel's default CI. Palm oil biodiesel's $\mathrm{CI}$ is $72 \mathrm{kgCO}_{2} \mathrm{eq} / \mathrm{mmBtu}\left(68 \mathrm{gCO}_{2} \mathrm{eq} / \mathrm{MJ}\right)$, approximately the same value as the EPA's $81 \mathrm{kgCO}_{2} \mathrm{eq} / \mathrm{mmBtu}$. In the UK as in the US, palm oil-based biodiesel's GHG savings of $19 \%$ cannot meet the $50 \%$ threshold.

Table 5. Bioliquid default carbon intensities and disaggregated default values [28].

\begin{tabular}{|c|c|c|c|c|c|}
\hline \multirow{2}{*}{$\begin{array}{c}\text { Bioliquid } \\
\text { Production Pathway }\end{array}$} & \multirow{2}{*}{$\begin{array}{c}\text { Default CI } \\
{\left[\mathrm{gCO}_{2} \mathrm{eq} / \mathrm{MJ}\right]}\end{array}$} & \multicolumn{3}{|c|}{ Disaggregated Default Values $\left[\mathrm{gCO}_{2} \mathrm{eq} / \mathrm{MJ}\right]$} & \multirow[b]{2}{*}{ GHG Saving } \\
\hline & & Cultivation & Processing & $\begin{array}{l}\text { Transport \& } \\
\text { Distribution }\end{array}$ & \\
\hline $\begin{array}{c}\text { Palm oil biodiesel } \\
\text { (process not specified) }\end{array}$ & 68 & 14 & 49 & 5 & $19 \%$ \\
\hline Rape seed biodiesel & 52 & 29 & 22 & 1 & $38 \%$ \\
\hline Soybean biodiesel & 58 & 19 & 26 & 13 & $31 \%$ \\
\hline $\begin{array}{l}\text { Waste vegetable or } \\
\text { animal biodiesel }\end{array}$ & 14 & 0 & 13 & 1 & $83 \%$ \\
\hline
\end{tabular}

Besides CI, the RTFO administrator, the Secretary of State for Transport, requires biofuel suppliers to submit verified data regarding the sustainability of the biofuel they supply. Most of the required information and criteria for sustainability, consisting of feedstock cultivation region, biodiversity, carbon stock and peat-lands, and cross compliance, are connected with the EU's RED.

Cultivation region: Obligators of the RTFO must demonstrate that feedstocks were sourced from a region where typical GHG emissions associated with their cultivation can be expected to be equal to or lower than the RED GHG default values (Appendix A). Regions are defined at the Nomenclature of Territorial Units for Statistics (NUTS2) level [28].

Biodiversity: To meet biodiversity criteria, as per land use restrictions of the RED, biofuels may not be made from raw material coming from land with a high biodiversity value at any point during or since January 2008 [28]. Here, high biodiversity value means primary forest and other wooded land of native species, where there is no clearly visible indication of human activity, and the ecological processes are not significantly disturbed (Appendix B). The EU also adopted a regulation for the definition of highly biodiverse grasslands, namely grassland that would remain grassland in the absence of human intervention, on 8 December 2014, which applies from 1 October 2015.

Carbon stock and peat-lands: Biofuels may not be made from raw materials obtained from land with high carbon stock or land that was undrained peat-land, like wetlands and forests, in January 2008, unless strict criteria are met (Appendix B).

Cross compliance: Biofuel feedstocks grown in the European community must be cultivated according to the European Commission's "Cross Compliance" requirements and must meet the minimum requirements for good agricultural and environmental conditions (Appendix C).

The RTFO program, like RED, also tries to promote the use of waste and residue feedstocks by double-counting biofuel produced from wastes, residues, non-food cellulosic material, and ligno-cellulosic material toward suppliers' obligations. This means that one liter of biofuel produced from wastes/residues will receive two Renewable Transport Fuel Certificates (RTFC).

Table 6 below indicates the carbon and sustainability data that fuel suppliers must report to the RTFO administrator. This reporting is crucial to proving compliance with the RED sustainability criteria and earning RFTCs. 
Table 6. Illustrative carbon and sustainability reporting data [28].

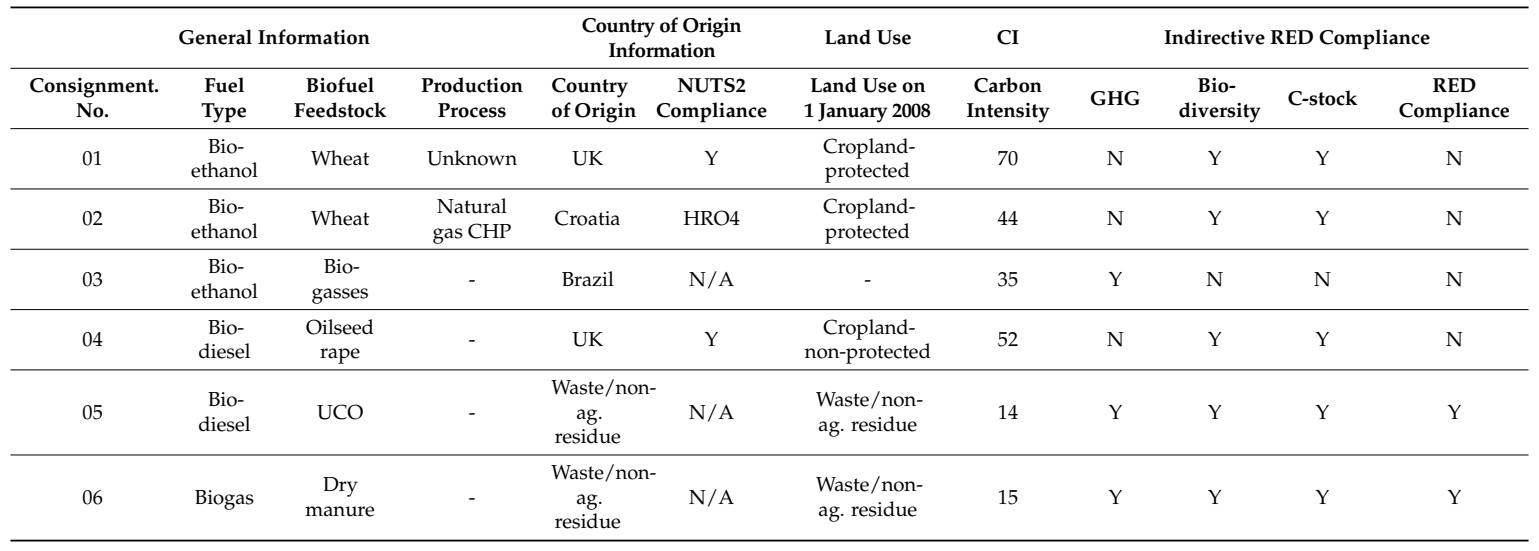

For example, the feedstock in consignment, 04 above, was cultivated in a compliant NUTS2 region, had no land-use change, and the land use on 1 January 2008 was reported as cropland-nonprotected. The carbon default of $52 \mathrm{gCO}_{2} \mathrm{eq} / \mathrm{MJ}$ can be reported. However, it does not meet the GHG saving threshold of 50\% introduced from 1 January 2017. It, therefore, does not meet the GHG saving and overall scores an ' $\mathrm{N}$ ' for RED compliance, as it does not meet the GHG criteria.

In Table 5, palm oil biodiesel's (process not specified) GHG savings of 19\% cannot meet the threshold of $50 \%$. However, if biodiesel is produced from palm oil at a production facility that captures $\mathrm{CH}_{4}$, as on the bottom row of Table 7, it can meet the threshold. As Table 7 shows, the CI of biodiesel (Methyl ester) from palm is $37 \mathrm{gCO}_{2} \mathrm{eq} / \mathrm{MJ}$, a $56 \%$ carbon savings, which can meet the threshold of $50 \%$.

Table 7. Process default values [28].

\begin{tabular}{|c|c|c|c|c|}
\hline Fuel & Feedstock & Process Characteristic & $\begin{array}{c}\mathrm{CI} \\
\left(\mathrm{gCO}_{2} \mathrm{eq} / \mathrm{MJ}\right)\end{array}$ & $\begin{array}{c}\text { Carbon } \\
\text { Saving (\%) }\end{array}$ \\
\hline \multirow{5}{*}{ Bioethanol, ETBE, TAME } & $\begin{array}{l}\text { Corn (produced } \\
\text { within the EU) }\end{array}$ & $\begin{array}{l}\text { Natural gas a process fuel } \\
\text { in CHP plant }\end{array}$ & 43 & 49 \\
\hline & \multirow{4}{*}{ Wheat } & $\begin{array}{l}\text { Lignite as process fuel in } \\
\text { CHP plant }\end{array}$ & 70 & 16 \\
\hline & & $\begin{array}{l}\text { Natural gas as process fuel } \\
\text { in conventional boiler }\end{array}$ & 55 & 34 \\
\hline & & $\begin{array}{l}\text { Natural gas as process fuel } \\
\text { in CHP plant }\end{array}$ & 44 & 47 \\
\hline & & $\begin{array}{l}\text { Straw as process fuel in } \\
\text { CHP plant }\end{array}$ & 26 & 69 \\
\hline Biodiesel (Methyl ester) & Palm & Methane capture at oil mill & 37 & 56 \\
\hline Biodiesel (HVO) & Palm & Methane capture at oil mill & 29 & 65 \\
\hline
\end{tabular}

Figure 8 shows the UK and Ireland carbon calculator, which is used by fuel suppliers and the Department of Transportation to reduce the potential for errors during calculation of CI. This software shows (a fuel lifecycle CI for Methyl ester biodiesel of $36.9 \mathrm{gCO}_{2} \mathrm{eq} / \mathrm{MJ}$, almost exactly the same as from Table 7 .

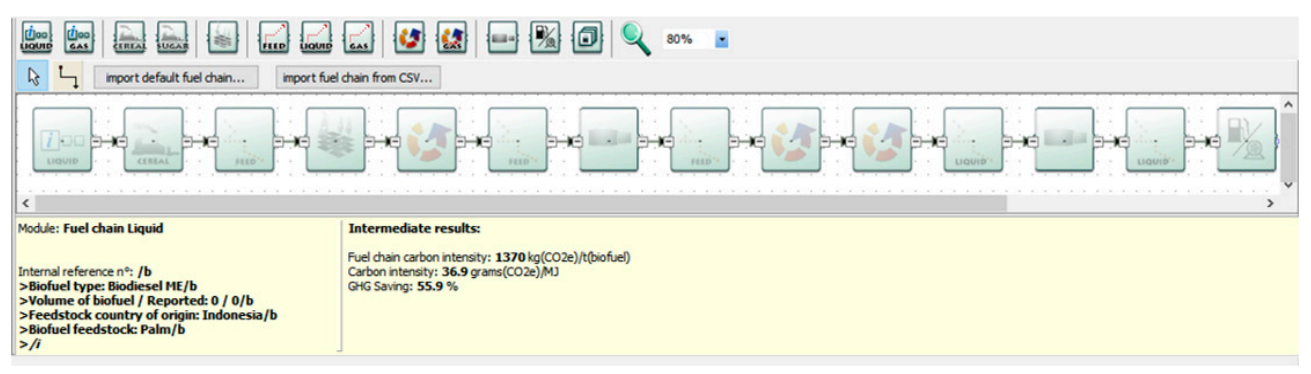

Figure 8. Illustrative carbon and sustainability reporting data. 
To expand the qualified yearly biofuel volume, the UK mandates obligators to supply biofuel and requires that they also meet the specified sustainability criteria. In April 2018, it was announced that the RTFO biofuel volume target would increase to $9.75 \%$ in 2020 and $12.4 \%$ in 2032 from the current $4.75 \%$. An initial cap of $4 \%$ crop-based biofuel is set for 2018 . The cap will be reduced annually from 2021 to reach $3 \%$ in 2026 and $2 \%$ in 2032 [45].

\subsection{Sustainability of Biodiesel in Korea}

The RFS program of Korea does not have specified source-based carbon savings and sustainability criteria for biofuels, unlike the US and UK. In other words, if a supplier in Korea provides $1000 \mathrm{~L}$ of biodiesel to a pump, calculated GHGs corresponding to that volume will be reduced regardless where the biodiesel came from and how much GHG will be emitted during the fuel's lifecycle. This aspect of the RFS program in Korea therefore does not follow the US and UK model of considering the overall sustainability of the biodiesel lifecycle.

Table 8 shows the biodiesel feedstocks used to manufacture biodiesel for domestic use in Korea for selected years from 2006 to 2015 [46]. Domestic UCO and imported PFAD have been the main feedstocks since 2010 and accounted for approximately 83\% of Korea's biodiesel in 2015. Biodiesel production companies have collected used cooking oil as a feedstock and imported PFAD to replace palm oil since 2010 [18].

Table 8. Raw material proportion of biodiesel in Korea, $10^{3}$ ton [46].

\begin{tabular}{|c|c|c|c|c|c|c|c|}
\hline & Feedstock & 2006 & 2008 & 2010 & 2012 & 2014 & 2015 \\
\hline \multirow{4}{*}{ Domestic } & $\mathrm{UCO}$ & 16 & 57 & 78 & 121 & 144.3 & 147.1 \\
\hline & Tallow & - & - & - & - & 14.9 & 27.4 \\
\hline & Others & 0.4 & 0.1 & - & - & 5.3 & 4.5 \\
\hline & Subtotal & 16.4 & 57.1 & 78 & 121 & 164.5 & 179.0 \\
\hline \multirow{7}{*}{ Imported } & Soybean & 46 & 69 & 80 & 19 & 3.5 & 2.8 \\
\hline & $\begin{array}{c}\text { Palm fatty acid distillate } \\
\text { (PFAD) }\end{array}$ & - & 30 & 102 & 136 & 154.8 & 169.6 \\
\hline & Palm oil & - & 34 & 69 & 62 & 21.4 & 28.3 \\
\hline & $\mathrm{UCO}$ & - & 0.1 & 25 & 38 & 34.8 & 34.5 \\
\hline & Tallow (Beef) & - & - & - & - & - & - \\
\hline & Others & - & 16 & 4 & 9 & 5.2 & 7.1 \\
\hline & Subtotal & 46 & 149.1 & 280 & 264 & 219.7 & 242.3 \\
\hline \multicolumn{2}{|r|}{ Total } & 62.4 & 149.1 & 280 & 385 & 384.2 & 421.5 \\
\hline \multicolumn{2}{|r|}{ Localization rate } & 26.3 & 27.7 & 21.8 & 31.4 & 42.8 & 42.5 \\
\hline
\end{tabular}

\subsection{Method}

GHG emissions for biodiesel from two of the four feedstocks that form the basis for most of Korea's biodiesel (tallow, palm oil) were calculated using the Argonne National Laboratory's Greenhouse gases, Regulated Emissions, and Energy use in Transportation (GREET) model suite (2014 version), which shows the total GHG emissions from biofuel cultivation to biofuel pump. Subsequently, the GHG emissions for UCO, tallow, palm oil, and PFAD (the four feedstocks most used in Korea) were calculated using the UK and Ireland carbon calculator, and the values for tallow and palm oil found using the UK and Ireland calculator were compared to the GREET values to confirm the accuracy of the results (GREET does not have UCO and PFAD). Using the results from the UK and Ireland calculator and the volume of each feedstock used in biodiesel for domestic consumption in 2015 (see Table 8), it was possible to calculate the total GHG resulting from the biodiesel portion of the transportation sector. That calculated emission was then compared to the total GHG from the transportation sector calculated using the emission factors from 2006 IPCC Guidelines for National Greenhouse Gas Inventories and treating biodiesel as carbon neutral.

\section{Results}

When the UK and Ireland carbon calculator was used to calculate GHG emissions for biodiesel based on the amounts of four feedstocks, UCO, tallow, palm oil, and PFAD, used in Korea in 2015, 
the total GHG for biodiesel were found to be $370.210^{3} \mathrm{tCO}_{2}$ eq. Table 9 shows the calculated values. In Table 9, the CI unit ( $\mathrm{gCO}_{2} \mathrm{eq} / \mathrm{MJ}$ ) reported by the UK and Ireland carbon calculator was converted to $\left(\mathrm{kgCO}_{2} \mathrm{eq} / \mathrm{t}\right)$ (biofuel) because domestic biodiesel feedstocks were reported in tons.

Table 9. GHG emissions of biodiesel usage in Korea in 2015 [28,46].

\begin{tabular}{|c|c|c|c|c|c|}
\hline & $10^{3}$ ton & Percent & $\mathrm{CI}\left(\mathrm{gCO}_{2} \mathrm{eq} / \mathrm{MJ}\right)$ & $\mathrm{CI}\left(\mathrm{kgCO}_{2} \mathrm{eq} / \mathrm{t}(\right.$ Biofuel) & GHG Emissions $\left(10^{3} \mathrm{tCO}_{2} \mathrm{eq}\right)$ \\
\hline $\mathrm{UCO}$ & 181.6 & $43 \%$ & 14 & 471 & 85.5 \\
\hline Tallow & 27.4 & $7 \%$ & 14 & 471 & 12.9 \\
\hline PFAD & 169.6 & $40 \%$ & 37 & 1370 & 232.4 \\
\hline Palm oil & 28.3 & $7 \%$ & 37 & 1370 & 39.5 \\
\hline Others & 14.4 & $3 \%$ & - & - & - \\
\hline Total & 421.5 & $100 \%$ & & & 370.2 \\
\hline
\end{tabular}

Table 10 shows the quantities of diesel and biodiesel used by Korea's transportation sector in 2015, as well as the GHG emissions when biodiesel is assumed to be carbon neutral. (The diesel GHG, $53,898.510^{3} \mathrm{tCO}_{2} \mathrm{eq}$, was calculated using the emission factors from 2006 IPCC Guidelines for National Greenhouse Gas Inventories.) Table 11 shows the quantities of diesel and biodiesel used and the GHG using the calculated GHG for biodiesel. The biodiesel quantity shown in Tables 10 and 11, $441.010^{3} \mathrm{TOE}$, is slightly different from the total quantity of biodiesel, $421.510^{3} \mathrm{TOE}$, shown in Table 9 because these tables were created based on statistics from different sources. The National Greenhouse Gas Inventory Report of Korea [47] provided the total quantity of biodiesel used, $441.010^{3} \mathrm{TOE}$. The quantities of individual feedstocks shown in Tables 8 and 9 were from the Bioenergy Association. Differences in quantities shown derive from differences in the time and method of investigation.

Table 10. Korea's transportation sector diesel and biodiesel quantity used and GHG emissions in 2015, assuming biodiesel is carbon neutral [47].

\begin{tabular}{|c|c|c|}
\hline & Energy Used $\left(10^{3} \mathrm{TOE}\right)$ & Total GHG Emission $\left(10^{3} \mathrm{tCO}_{2} \mathrm{eq}\right)$ \\
\hline Diesel & $17,358.0$ & $53,898.5$ \\
\hline Biodiesel & 441.0 & - \\
\hline Total & $17,799.0$ & $53,898.5$ \\
\hline
\end{tabular}

Table 11. Korea's transportation sector diesel and biodiesel quantity used and GHG emissions in 2015, including calculated GHG for biodiesel [47].

\begin{tabular}{ccccc}
\hline & Energy Used $\left(\mathbf{1 0}^{\mathbf{3}} \mathbf{T O E}\right)$ & $\mathbf{\%}$ of Total & Total GHG Emission $\left(\mathbf{1 0}^{\mathbf{3}} \mathbf{t} \mathbf{C O}_{\mathbf{2}} \mathbf{e q}\right)$ & $\mathbf{\%}$ of Total \\
\hline Diesel & $17,358.0$ & 97.5 & $53,898.5$ & 99.3 \\
Biodiesel & 441.0 & 2.5 & 370.2 & 0.7 \\
Total & $17,799.0$ & 100.0 & $54,268.7$ & 100.0 \\
\hline
\end{tabular}

As Table 11 shows, at B2.5, the RFS blend ratio in 2015, GHG emissions from biodiesel represent $0.7 \%$ of total diesel and biodiesel GHG.

To calculate the reduction in GHG resulting from biodiesel, Table 12 shows the predicted GHG emissions in a no-biodiesel (100\% diesel) scenario. As Table 12 shows, in a no-biodiesel scenario, GHG is $55,267.910^{3} \mathrm{tCO}_{2} \mathrm{eq}$, a net increase of $999.210^{3} \mathrm{tCO}_{2} \mathrm{eq}$

Table 12. Predicted 2015 GHG emissions in a no-biodiesel scenario.

\begin{tabular}{ccccc}
\hline & \multicolumn{2}{c}{ No-Biodiesel Scenario } & \multicolumn{2}{c}{ GHG Emission $\left(\mathbf{1 0}^{3} \mathbf{t C O}_{\mathbf{2}} \mathbf{e q}\right)$} \\
\cline { 2 - 5 } & $\mathbf{1 0 ^ { 3 }}$ TOE & Amount inc/dec & GHG Total & Amount inc/dec \\
\hline Diesel & $17,799.0$ & +441.0 & $55,267.9$ & $+1,369.4$ \\
Biodiesel & 0.0 & -441.0 & 0.0 & -370.2 \\
\hline \multicolumn{2}{c}{ Net increase in GHG in a no-biodiesel scenario } & +999.2 \\
\hline
\end{tabular}




\section{Discussion}

In the transportation sector, the Korean government's long-term GHG reduction goals include developing EV infrastructure and promoting eco-friendly public transportation; but as a transitional phase, the RFS is a significant component of the current GHG mitigation plan [48]. As this research shows, biodiesel does promote significant carbon savings by comparison to petroleum-based diesel; however, biodiesel is not carbon neutral, and the difference in carbon savings based on different feedstocks is quite significant. Moreover, long-term soil degradation, loss of biodiversity, and excessive water use associated with feedstocks such as palm oil create environmental costs whose future effects cannot be fully anticipated and that are in addition to the environmental impact of GHG emissions. Therefore, Korea's RFS program could be improved by including sustainability criteria like the ones included in the US's RFS and the UK's RTFO that do not regard biofuels as inherently carbon neutral, but instead consider the GHG costs of DLUC and ILUC, as well as lifecycle GHG emissions.

PFAD, accounting for 40\% of Korea's biodiesel feedstock in 2015, is also questionable in terms of its sustainability. In Norway and Sweden, PFAD was not categorized as a coproduct but as a residue. Because the primary lifecycle environmental cost of manufacturing a product is associated with products and co-products but not residues, a residue is understood to carry a lower environmental cost [49]. Therefore, when PFAD is defined as a residue, it appears to be superior to palm oil in sustainability. However, when PFAD is reclassified as a coproduct, its sustainability is no better than palm oil's, rendering it unsuitable as a biofuel feedstock. In addition, palm oil, like petroleum, is a raw material that must be imported and therefore does not contribute to Korea's overall energy security. Consequently, the inclusion of PFAD is a significant weakness of Korea's RFS program. In order to promote energy security while reducing carbon cost, Korea should explore the potential of domestic feedstocks such as microalgae and food and agricultural waste.

UCO, which provided the feedstock for 35\% of Korea's biodiesel in 2015, represents an increasing percentage of Korea's biodiesel, and with one of the lowest CIs of the biodiesels at $14 \mathrm{gCO}_{2} \mathrm{eq} / \mathrm{MJ}$, yields an $83 \%$ carbon saving [28]. The Korean government plans to increase the role of UCO in Korea's biodiesel portfolio. However, UCO has already met its limited domestic supply potential, so increasing the share of biodiesel feedstock from UCO means, again, relying on an imported energy product. At this time, the Korean government is promoting development of technologies to produce biodiesel from tallow and waste oil, as shown Table 13, which, if successful, would be preferable alternatives to imported UCO.

Table 13. Ranking of supply potential of biodiesel feedstocks [18].

\begin{tabular}{|c|c|c|c|c|}
\hline Feedstock & $\begin{array}{l}\text { The Amount that } \\
\text { Can Be Secured }\end{array}$ & Feedstock Cost & $\begin{array}{c}\text { Unit Cost } \\
\text { of Production }\end{array}$ & $\begin{array}{c}\text { Ranking } \\
\text { Supply Potential }\end{array}$ \\
\hline Palm and PFAD & 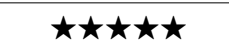 & 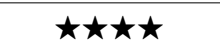 & 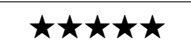 & 1 \\
\hline Domestic UCO & 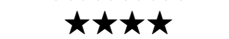 & 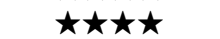 & 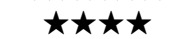 & 2 \\
\hline Domestic tallow & $\star \star \star \star$ & 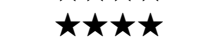 & 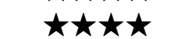 & 3 \\
\hline Domestic waste oil & $\star \star \star$ & 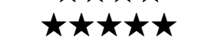 & $\star \star \star$ & 4 \\
\hline Domestic rape oil & 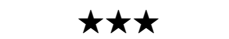 & $\star$ & 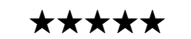 & 5 \\
\hline Domestic Microalgae & $\star$ & $\star$ & $\star$ & 6 \\
\hline
\end{tabular}

In developing the sustainability components of the RFS program, the Korean government needs to review the international certification program Roundtable on Sustainable Biofuels (RSB), as well as other countries' policies. By applying the international standard, Korea can avoid risks associated with adopting a policy developed for another country with a different energy profile.

Finally, with respect to the development of EV technology and the environmental cost of clean energy, Tessum et al. found that EVs charged from the current grid average did not have lower net environmental impact than combustion engine vehicles [50]. The current grid average is limited in its sustainability by each country's major power suppliers, which means that the overall environmental benefit of EVs is a factor of the overall power industry. Therefore, the immediate GHG mitigation impact of EVs will be low in countries with power grids more heavily dependent on coal and natural 
gas and higher in countries with more wind, solar, and other renewable energy sources. Even so, the price of EVs is still too expensive for most consumers. However, as EV and grid technology develops, the EV sticker price will go down, reducing the economic burden on consumers of selecting the lower-emission option and removing the barrier of cost that may prevent some consumers from making the switch. Likewise, most of the current biofuels are not perfectly environmentally friendly energy sources, and some feedstocks have significant environmental costs. In addition, the per-litre cost of biofuel blended fuels is higher for consumers, an economic burden that should be taken into account as the RFS program is adapted to meet ongoing GHG reduction goals.

\section{Conclusions}

In April 2018, the EU tightened its rules for biofuels by banning palm oil. The RFS is the one of Korea's primary mechanisms for reducing GHG emission in the transportation sector in order to implement the INDC plan. Korea, which emitted 585 million $\mathrm{tCO}_{2}$ in 2015, ranking seventh in total emissions by country, does not have carbon saving and sustainability criteria and instead treats all biodiesel as carbon neutral. However, this study found that when the UK and Ireland carbon calculator was used to calculate GHG emissions for biodiesel used in Korea in 2015, the total GHG for biodiesel was $370.210^{3} \mathrm{tCO}_{2}$ eq. As the RFS is the main program for mitigating $\mathrm{CO}_{2}$ emissions from the transportation sector, the RFS should take into account the feedstock's lifecycle GHG. Therefore, the introduction of new criteria into the RFS program should be considered urgent. Development of environmentally friendly vehicles is not sufficient to mitigate GHG emissions. Much greater potential impact can be expected from a more aggressive RFS program that includes a consideration of LCA.

Author Contributions: The authors have contributed to the article accordingly; conceptualization, J.-Y.S. and K.-Y.K.; methodology, J.-Y.S., K.-Y.K., and J.S.Z.; software, J.-Y.S. and K.-Y.K.; investigation, J.-Y.S., G.-W.K., and J.S.Z.; writing-original draft preparation, J.-Y.S.; writing-review and editing, J.-Y.S., G.-W.K., K.-Y.K., and J.S.Z.; supervision, J.-Y.S., K.-Y.K.

Funding: This work was supported by the Dongguk University Research Fund of 2018 (S-2018-G0001-00066).

Conflicts of Interest: The authors declare no conflict of interest.

\section{Glossary}

$\begin{array}{ll}\text { Symbol/Acronym } & \text { Description } \\ \mathrm{B} & \text { Biodiesel } \\ \mathrm{CH}_{4} & \text { Methane } \\ \mathrm{CI} & \text { Carbon Intensity } \\ \mathrm{CO}_{2} & \text { Carbon Dioxide } \\ \mathrm{DfT} & \text { Department for Transportation } \\ \mathrm{DLUC} & \text { Direct Land Use Change } \\ \text { EISA } & \text { Energy Independence and Security Act } \\ \text { EPA } & \text { Environmental Protection Agency } \\ \text { ETBE } & \text { Ethyl tert-butyl ether } \\ \text { EU RED } & \text { EU Renewable Energy Directive } \\ \text { EVs } & \text { Electric Vehicles } \\ \text { FAME } & \text { Fatty Acid Methyl Ester } \\ \text { FFB } & \text { Fresh Fruit Bunches } \\ \text { GREET } & \text { Greenhouse Gases, Regulated Emissions, and Energy Use in Transportation } \\ \text { GHG } & \text { Greenhouse Gas } \\ \text { HVO } & \text { Hydrotreated Vegetable Oil } \\ \text { IEA } & \text { International Energy Agency } \\ \text { ILUC } & \text { Indirect Land Use Change } \\ \text { INDC } & \text { Intended Nationally Determined Contribution } \\ \text { KEA } & \text { Korea Energy Agency }\end{array}$




$\begin{array}{ll}\text { K-Petro } & \text { Korea Petroleum Quality \& Distribution Authority } \\ \text { LCA } & \text { Lifecycle Assessment } \\ \text { LUC } & \text { Land Use Change } \\ \text { NUTS2 } & \text { Nomenclature of Territorial Units for Statistics } \\ \text { PFAD } & \text { Palm Fatty Acid Distillate } \\ \text { RFS } & \text { Renewable Fuel Standards } \\ \text { RO } & \text { Renewables Obligation } \\ \text { RSB } & \text { Roundtable on Sustainable Biofuels } \\ \text { RTFO } & \text { Renewable Transport Fuel Obligation } \\ \text { RTFC } & \text { Renewable Transport Fuel Certificates } \\ \text { UCO } & \text { Used Cooking Oil } \\ \text { WWF } & \text { World Wildlife Fund }\end{array}$

\section{Appendix A}

Directive 2009/28/EC of the European Parliament and of the council of 23 April 2009, Annex V.

Rules for calculating the greenhouse gas impact of biofuels, bioliquids and their fossil fuel comparators.

D. Disaggregated default values for biofuels and bioliquids.

Table A1. Total for cultivation, procession, transport and distribution.

\begin{tabular}{|c|c|c|}
\hline $\begin{array}{l}\text { Biofuel and Bioliquid } \\
\text { Production Pathway }\end{array}$ & $\begin{array}{l}\text { Typical Greenhouse Gas } \\
\text { Emissions }\left(\mathrm{gCO}_{2} \mathrm{eq} / \mathrm{MJ}\right)\end{array}$ & $\begin{array}{l}\text { Default Greenhouse Gas } \\
\text { Emissions }\left(\mathrm{gCO}_{2} \mathrm{eq} / \mathrm{MJ}\right)\end{array}$ \\
\hline Sugar beet ethanol & 33 & 40 \\
\hline Wheat ethanol (process fuel not specified) & 57 & 70 \\
\hline $\begin{array}{l}\text { Wheat ethanol (lignite as process fuel in } \\
\text { CHP plant) }\end{array}$ & 57 & 70 \\
\hline $\begin{array}{l}\text { Wheat ethanol (natural gas as process fuel } \\
\text { in conventional boiler) }\end{array}$ & 46 & 55 \\
\hline $\begin{array}{l}\text { Wheat ethanol (natural gas as process fuel } \\
\text { in CHP plant) }\end{array}$ & 39 & 44 \\
\hline $\begin{array}{l}\text { Wheat ethanol (straw as process fuel in } \\
\text { CHP plant) }\end{array}$ & 26 & 26 \\
\hline $\begin{array}{l}\text { Corn (maize) ethanol, Community } \\
\text { produced (natural gas as process fuel in } \\
\text { CHP plant) }\end{array}$ & 37 & 43 \\
\hline Sugar cane ethanol & 24 & 24 \\
\hline The part from renewable sources of ETBE & \multirow{2}{*}{\multicolumn{2}{|c|}{$\begin{array}{l}\text { Equal to that of the ethanol production pathway used } \\
\text { Equal to that of the ethanol production pathway used }\end{array}$}} \\
\hline The part from renewable sources of TAEE & & \\
\hline Rape seed biodiesel & 46 & 52 \\
\hline Sunflower biodiesel & 35 & 41 \\
\hline Soybean biodiesel & 50 & 58 \\
\hline Palm oil biodiesel (process not specified) & 54 & 68 \\
\hline $\begin{array}{l}\text { Palm oil biodiesel (process with methane } \\
\text { capture at oil mill) }\end{array}$ & 32 & 37 \\
\hline Waste vegetable or animal oil biodiesel & 10 & 14 \\
\hline Hydrotreated vegetable oil from rape seed & 41 & 44 \\
\hline Hydrotreated vegetable oil from sunflower & 29 & 32 \\
\hline $\begin{array}{l}\text { Hydrotreated vegetable oil from palm oil } \\
\text { (process not specified) }\end{array}$ & 50 & 62 \\
\hline $\begin{array}{l}\text { Hydrotreated vegetable oil from palm oil } \\
\text { (process with methane capture at oil mill) }\end{array}$ & 27 & 29 \\
\hline Pure vegetable oil from rape seed & 35 & 36 \\
\hline $\begin{array}{l}\text { Biogas from municipal organic waste as } \\
\text { compressed natural gas }\end{array}$ & 17 & 26 \\
\hline Biogas from wet manure as CNG & 13 & 16 \\
\hline Biogas from dry manure as CNG & 12 & 15 \\
\hline
\end{tabular}




\section{Appendix B}

Directive 2009/28/EC of the European Parliament and of the council of 23 April 2009, Article 17. Sustainability criteria for biofuels and bioliquids.

1. Irrespective of whether the raw materials were cultivated inside or outside the territory of the Community, energy from biofuels and bioliquids shall be taken into account for the purposes referred to in points (a), (b) and (c) only if they fulfil the sustainability criteria set out in paragraphs 2 to 6 :

(a) Measuring compliance with the requirements of this Directive concerning national targets;

(b) Measuring compliance with renewable energy obligations;

(c) Eligibility for financial support for the consumption of biofuels and bioliquids.

However, biofuels and bioliquids produced from waste and residues, other than agricultural, aquaculture, fisheries and forestry residues, need only fulfil the sustainability criteria set out in paragraph 2 in order to be taken into account for the purposes referred to in points (a), (b) and (c).

2. The greenhouse gas emission saving from the use of biofuels and bioliquids taken into account for the purposes referred to in points (a), (b) and (c) of paragraph 1 shall be at least $35 \%$. With effect from 1 January 2017, the greenhouse gas emission saving from the use of biofuels and bioliquids taken into account for the purposes referred to in points (a), (b) and (c) of paragraph 1 shall be at least $50 \%$. From 1 January 2018 that greenhouse gas emission saving shall be at least $60 \%$ for biofuels and bioliquids produced in installations in which production started on or after 1 January 2017. The greenhouse gas emission saving from the use of biofuels and bioliquids shall be calculated in accordance with Article 19 (1). In the case of biofuels and bioliquids produced by installations that were in operation on 23 January 2008, the first subparagraph shall apply from 1 April 2013.

3. Biofuels and bioliquids taken into account for the purposes referred to in points (a), (b) and (c) of paragraph 1 shall not be made from raw material obtained from land with high biodiversity value, namely land that had one of the following statuses in or after January 2008, whether or not the land continues to have that status:

(a) Primary forest and other wooded land, namely forest and other wooded land of native species, where there is no clearly visible indication of human activity and the ecological processes are not significantly disturbed;

(b) Areas designated:

(i) By law or by the relevant competent authority for nature protection purposes; or

(ii) For the protection of rare, threatened or endangered ecosystems or species recognized by international agreements or included in lists drawn up by intergovernmental organizations or the International Union for the Conservation of Nature, subject to their recognition in accordance with the second subparagraph of Article 18(4); unless evidence is provided that the production of that raw material did not interfere with those nature protection purposes;

(c) Highly biodiverse grassland that is:

(i) Natural, namely grassland that would remain grassland in the absence of human intervention and which maintains the natural species composition and ecological characteristics and processes; or

(ii) Non-natural, namely grassland that would cease to be grassland in the absence of human intervention and which is species-rich and not degraded, unless evidence is provided that the harvesting of the raw material is necessary to preserve its grassland status.

The Commission shall establish the criteria and geographic ranges to determine which grassland shall be covered by point (c) of the first subparagraph. Those measures, designed to amend nonessential elements of this Directive, by supplementing it shall be adopted in accordance with the regulatory procedure with scrutiny referred to in Article 25(4).

4. Biofuels and bioliquids taken into account for the purposes referred to in points (a), (b) and (c) of paragraph 1 shall not be made from raw material obtained from land with high carbon stock, namely land that had one of the following statuses in January 2008 and no longer has that status:

(a) Wetlands, namely land that is covered with or saturated by water permanently or for a significant part of the year;

(b) Continuously forested areas, namely land spanning more than one hectare with trees higher than five meters and a canopy cover of more than $30 \%$, or trees able to reach those thresholds in situ;

(c) Land spanning more than one hectare with trees higher than five meters and a canopy cover of between $10 \%$ and $30 \%$, or trees able to reach those thresholds in situ, unless evidence is provided that the carbon stock of the area before and after conversion is such that, when the methodology laid 
down in part $\mathrm{C}$ of Annex $\mathrm{V}$ is applied, the conditions laid down in paragraph 2 of this Article would be fulfilled.

The provisions of this paragraph shall not apply if, at the time the raw material was obtained, the land had the same status as it had in January 2008.

\section{Appendix C}

Council Regulation (EC) No 73/2009 of 19 January 2009, Annex III.

Table A2. Good agricultural and environmental condition.

\begin{tabular}{|c|c|c|}
\hline Issue & Compulsory Standards & Optional Standards \\
\hline $\begin{array}{l}\text { Soil erosion: Protect soil through } \\
\text { appropriate measures }\end{array}$ & $\begin{array}{l}\text { Minimum soil cover } \\
\text { Minimum land management } \\
\text { reflecting site-specific conditions }\end{array}$ & Retain terraces \\
\hline $\begin{array}{l}\text { Soil organic matter: Maintain soil } \\
\text { organic matter levels through } \\
\text { appropriate practices }\end{array}$ & Arable stubble management & Standards for crop rotations \\
\hline $\begin{array}{l}\text { Soil structure: Maintain soil structure } \\
\text { through appropriate measures }\end{array}$ & & Appropriate machinery use \\
\hline \multirow{4}{*}{$\begin{array}{l}\text { Minimum level of maintenance: } \\
\text { Ensure a minimum level of } \\
\text { maintenance and avoid the } \\
\text { deterioration of habitats }\end{array}$} & \multirow{2}{*}{$\begin{array}{l}\text { Retention of landscape features, } \\
\text { including, where appropriate, hedges, } \\
\text { ponds, ditches trees in line, in group }\end{array}$} & $\begin{array}{l}\text { Minimum livestock stocking rates } \\
\text { or/and appropriate regimes }\end{array}$ \\
\hline & & $\begin{array}{l}\text { Establishment and/or retention } \\
\text { of habitats }\end{array}$ \\
\hline & $\begin{array}{l}\text { Avoiding the encroachment of } \\
\text { unwanted veg }\end{array}$ & $\begin{array}{l}\text { Prohibition of the grubbing up of } \\
\text { olive trees }\end{array}$ \\
\hline & Protection of permanent pasture & $\begin{array}{l}\text { Maintenance of olive groves and } \\
\text { vines in good vegetative condition }\end{array}$ \\
\hline $\begin{array}{l}\text { Protection and management of water: } \\
\text { Protect water against pollution and } \\
\text { run-off, and manage the use of water }\end{array}$ & $\begin{array}{l}\text { Establishment of buffer strips along } \\
\text { water courses (1) } \\
\text { Where use of water for irrigation is } \\
\text { subject to authorization, compliance } \\
\text { with authorization procedures }\end{array}$ & \\
\hline
\end{tabular}

(1) Note: The GAEC buffer strips must respect, both within and outside vulnerable zones designated pursuant to Article 3(2) of Directive 91/676/EEC, at least the requirements relating to the conditions for land application of fertilizer near water courses, referred to in point A.4 of Annex II to Directive 91/676/EEC to be applied in accordance with the action programs of Member States established under Article 5(4) of Directive 91/676/EEC.

\section{References}

1. Union of Concerned Scientists. Each Country's Share of $\mathrm{CO}_{2}$ Emission. Available online: https:/ / www.ucsusa. org/global-warming/science-and-impacts/science/each-countrys-share-of-co2.html\#.WurW3ogvzIU (accessed on 1 October 2018).

2. Chow, E.; Thukral, N. Malaysia to Respond with 'Might and Tact' If EU proceeds with Palm Oil Curbs. JakartaGlobe. Available online: https://jakartaglobe.id/international/malaysia-respond-might-tact-euproceeds-palm-oil-curbs-minister/ (accessed on 1 October 2018).

3. Renewables 2017 Global Status Report; REN21 Secretariat: Paris, France, 2017; pp. 45-51. ISBN 978-3-9818107-6-9.

4. Energy and Climate Change: World Energy Outlook Special Report; OECD/IEA: Paris, France, 2015; Available online: https: //www.iea.org/publications/freepublications/publication/WEO2015SpecialReportonEnergyandClimateChange. pdf (accessed on 1 October 2018).

5. DeCicco, J. Biofuels turn out to be a climate mistake - here's why. Available online: https://theconversation. com/biofuels-turn-out-to-be-a-climate-mistake-heres-why-64463 (accessed on 1 October 2018).

6. 2017 global fuel ethanol production by country [Chart]. In 2018 Ethanol Industry Outlook; Renewable Fuels Association (RFA): Washington, DC, USA, 2018; p. 13. Available online: http:/ / www.ethanolresponse.com/ wp-content/uploads/2018/02/2018-RFA-Ethanol-Industry-Outlook.pdf (accessed on 1 October 2018). 
7. Renewable energy consumption [Figure 10.1]. In Monthly Energy Review; U.S. Energy Information Administration, Government Printing Office: Washington, DC, USA, 2018. Available online: https:/ /www.eia.gov/totalenergy/ data/monthly/pdf/sec10_2.pdf (accessed on 1 October 2018).

8. Fargione, J.; Hill, J.; Tilman, D.; Polasky, S.; Hawthorne, P. Land clearing and the biofuel carbon debt. Science 2008, 319, 1235-1238. [CrossRef] [PubMed]

9. Searchinger, T.; Heimlich, R.; Houghton, R.A.; Dong, F.; Elobeid, A.; Fabiosa, J.; Tokgoz, S.; Hayes, D.; Yu, T. Use of U.S. croplands for biofuels increases greenhouse gases through emissions from land-use change. Science 2008, 319, 1238-1240. [CrossRef]

10. Fredriksson, G.; Roth, A.; Tagliapietra, S.; Zachmann, G. The Impact of Brexit on the EU Energy System; IP/A/ITRE: Brussels, Belgium, 2017; ISBN 978-92-846-2255-9. Available online: http:/ /www.europarl.europa.eu/RegData/ etudes/STUD/2017/614181/IPOL_STU(2017)614181_EN.pdf (accessed on 2 October 2018).

11. Valin, H.; Peters, D.; Van den Berg, M.; Frank, S.; Havlik, P.; Forsell, N.; Hamelinck, C. The Land Use Change Impact of Biofuels Consumed in the EU: Quantification of Area and Greenhouse Gas Impacts; Ecofys: Utrecht, The Netherlands, 2015; Available online: https:/ / ec.europa.eu/energy/sites/ener/files/ documents /Final\%20Report_GLOBIOM_publication.pdf (accessed on 1October 2018).

12. Nelson, A. MEPs vote to ban the use of palm oil in biofuels. The Guardian, 4 April 2017. Available online: https:/ / www.theguardian.com/sustainable-business/2017/apr/04/palm-oil-biofuels-meps-eutransport-deforestation-zsl-greenpeace-golden-agri-resources-oxfam(accessed on 11 November 2018).

13. The EU's war on palm oil. Available online: https://www.aseantoday.com/2018/03/the-eus-war-on-palmoil/ (accessed on 11 November 2018).

14. Observatory of Economic Complexity (OEC). Indonesia. Available online: https://atlas.media.mit.edu/en/ profile/country/idn/ (accessed on 2 October 2018).

15. Guillaume, T.; Kotowska, M.; Hertel, D.; Knohl, A.; Krashevska, V.; Kukuh, M.; Scheu, S.; Kuzyakov, Y. Carbon costs and benefits of Indonesian rainforest conversion to plantations. Nat. Commun. 2018, 9, 2388. [CrossRef]

16. Renewable Transport Fuel Obligation (RTFO). Available online: http://mrl.uk.com/renewable-transportfuel-obligation-rtfo/ (accessed on 11 November 2018).

17. Renewable Transport Fuel Obligation Guidance Part One: Process Guidance Year 11: 15/4/18 to 31/12/18. Moving Britain Ahead; Department for Transport: London, UK, 2018. Available online: https:/ / assets.publishing.service.gov.uk/government/ uploads/system/uploads/attachment_data/file/694277/rtfo-guidance-part-1-process-guidance-year-11.pdf (accessed on 2 October 2018).

18. Kim, J.G.; Min, K.I.; Jang, E.J.; Kim, S.; Lee, D.M.; Park, J.Y.; Lee, M.E.; Choi, W.H.; Ahn, S.H. Study on Establishment of Biofuel Promotion Policy for Transportation; K-Petro: Seongnam, Korea, 2016.

19. A Road Map to Cut Greenhouse Gas Emissions by 37 Percent. Available online: http://2030ghg.or.kr/ references / ? mod=document\&uid=15 (accessed on 10 November 2018).

20. Yoon, B.H. The new government stresses renewable energy and will increase blend rate of biodiesel. Available online: http:/ / www.ebn.co.kr/news/view/902953 (accessed on 2 October 2018).

21. Kim, B.H. Palm Plantation Indiscriminate Felling. Emits Three Times More Greenhouse Gas Emissions than Diesel. Available online: http:/ / news.hankyung.com/article/2018031895191 (accessed on 2 October 2018).

22. Shim, N.Y. Let's Reduce Carbon. The Diesel Price Will Grow Again Next Year. Available online: http: / / www.asiae.co.kr/news / view.htm?idxno=2017102022481273270 (accessed on 2 October 2018).

23. Biodiesel Rate Will Be Increased in Diesel. So, What about the Price of Oil. Available online: http://www. yonhapnews.co.kr/bulletin/2015/03/03/0200000000AKR20150303187100003.HTML (accessed on 2 October 2018).

24. Kang, K.J. \$46 million additional burden is expected to refineries in Korea by RFS. Available online: http: / / news.joins.com/article/18415013 (accessed on 2 October 2018).

25. An, Y.I. Can biofuel work to reduce GHGs? Available online: https://news.sbs.co.kr/news/endPage.do? news_id=N1002850508 (accessed on 2 October 2018).

26. Renewable Fuel Standard. Available online: https://www.knrec.or.kr/business/rfs_about.aspx (accessed on 11 November 2018).

27. Renewable Fuel Standard Program. Available online: https://www.epa.gov/renewable-fuel-standardprogram/overview-renewable-fuel-standard (accessed on 11 November 2018). 
28. Renewable Transport Fuel Obligation Guidance Part Two: Carbon and Sustainability Year 11: 15/4/18 to 31/12/18. Moving Britain Ahead; Department for Transport: London, UK, 2018; Available online: https://assets. publishing (accessed on 11 November 2018).

29. Sustainability of Bioenergy; Commission Staff Working Document: Impact Assessment; European Commission: Brussels, Belgium, 2016; Available online: https:/ / ec.europa.eu/energy/sites/ener/files/documents/1_en_ impact_assessment_part4_v4_418.pdf (accessed on 2 October 2018).

30. Statutes for Renewable Fuel Standard Program. Available online: https:/ / www.epa.gov/renewable-fuelstandard-program/statutes-renewable-fuel-standard-program (accessed on 11 November 2018).

31. Hamelinck, C.; Zabeti, M. Low Carbon Biofuels for the UK; Ecofys: Utrecht, The Netherlands, 2016; Available online: https: / / epure.org/media/1418/ecofys-2016-low-carbon-biofuels-for-the-uk.pdf (accessed on 11 November 2018).

32. Renewable Fuel Standard Program. U.S. Environmental Protection Agency (EPA), Last updated 19 September 2018. Available online: https:/ / www.epa.gov/renewable-fuel-standard-program (accessed on 2 October 2018).

33. Fuel Pathways under Renewable Fuel Standard. EPA, Last Updated 6 June 2017. Available online: https: / / www.epa.gov/renewable-fuel-standard-program/fuel-pathways-under-renewable-fuel-standard (accessed on 2 October 2018).

34. Enström, A. GHG Reduction with Solid Separation in POME Ponds: Introducing New Emission Factors for Alternative CH4 Reduction Techniques. Available online: https:/ / www.iscc-system.org/wp-content/ uploads/2017/08/2.-Reducing-the-Impact-of-Methane-Emissions-2.pdf (accessed on 2 October 2018).

35. Overview for Renewable Fuel Standard. EPA, Last Updated 7 June 2017. Available online: https: / / www. epa.gov / renewable-fuel-standard-program/overview-renewable-fuel-standard\#pathways (accessed on 2 October 2018).

36. Lifecycle Greenhouse Gas Emissions for Select Pathways [Table]. EPA. 2016. Available online: https: / / www.epa.gov/sites/production/files/2016-07/documents/select-ghg-results-table-v1.pdf (accessed on 2 October 2018).

37. EPA Issues Notice of Data Availability Concerning Renewable Fuels Produced from Palm Oil under the RFS Program. EPA, Office of Transportation and Air Quality. 2011. Available online: https:/ /www.epa.gov/ sites / production/files/2015-08/documents/420f11046.pdf (accessed on 2 October 2018).

38. Kotrba, R. US Biodiesel Production, Imports Remain Strong Amid Uncertainty. Available online: http:/ / www. biodieselmagazine.com/articles/2516126/us-biodiesel-production-imports-remain-strong-amid-uncertainty (accessed on 2 October 2018).

39. Elgowainy, A.; Han, J.; Ward, J.; Joseck, F.; Gohlke, D.; Lindauer, A.; Ramsden, T.; Biddy, M.; Alexander, M.; Barnhart, S.; et al. Cradle-to-Grave Lifecycle Analysis of US Light-Duty Vehicle-Fuel Pathways: A Greenhouse Gas Emissions and Economic Assessment of Current (2015) and Future (2025-2030) Technologies; Argonne National Laboratory, Energy Systems Division: Chicago, IL, USA, 2016. Available online: https:/ /greet.es.anl.gov/ publication-c2g-2016-report (accessed on 2 October 2018).

40. Neslen, A. UK Defies EU over Indonesian Palm Oil Trade. The Guardian. 9 March 2018. Available online: https:/ / www.theguardian.com/environment/2018/mar/09/uk-defies-eu-over-indonesian-palmoil-trade-leaked-papers-show (accessed on 2 October 2018).

41. Richards, A. Iceland Supermarket Vows to Ban Palm Oil in Own-Brand Products. Evening Standard. Available online: https:/ / www.standard.co.uk/news/uk/iceland-supermarket-vows-to-ban-palm-oil-inownbrand-products-a3810141.html (accessed on 2 October 2018).

42. Renewable Energy Association (REA) News. UK Palm Oil-Based Biodiesel Consumption Is Zero to Date in 2015/16. 31 May 2016. Available online: https://www.r-e-a.net/news/uk-palm-oil-based-biodieselconsumption-is-zero-to-date-in-2015-16 (accessed on 2 October 2018).

43. Renewables Obligation: Sustainability Criteria; Ofgem, Fuelling and Sustainability Team, Renewable Electricity: London, UK, 2016. Available online: https:/ / www.ofgem.gov.uk/system/files/docs/2016/03/ofgem_ro_ sustainability_criteria_guidance_march_16.pdf (accessed on 2 October 2018).

44. Directive 2009/28/EC of the European Parliament and of the Council of 23 April 2009 on the Promotion of the Use of Energy from Renewable Sources and Amending and Subsequently Repealing Directives 2001/77/EC and 2003/30/EC. Official Journal of the European Union. 2009. Available online: https:/ / eur-lex.europa.eu/legalcontent/EN/TXT/PDF/?uri=CELEX:32009L0028\&from=EN (accessed on 2 October 2018). 
45. New UK Biofuel Targets Take Effects April 15. Revista RPAnews. Available online: http:/ / revistarpanews.com. br/noticias / 64-internacional/5748-new-uk-biofuel-targets-take-effect-april-15 (accessed on 2 October 2018).

46. Hong, W.A. Study on the Improvement of the Cold Properties of Biodiesel and Biodiesel-Blended. Master's Thesis, Seoul National University of Science and Technology, Seoul, Korea, 2017. Available online: http: / / www.riss.kr/link?id=T14733130 (accessed on 2 October 2018).

47. National Greenhouse Gas Inventory Report of Korea; Greenhouse Gas Inventory and Research Center: Seoul, Korea, 2017; Available online: http://www.gir.go.kr/home/board/read.do;jsessionid= D12BTno8jLQAFQTQLXOvEWZEB633Q2RJVbXS9E23Oc72O0xCM8JxzCNaDhjgVUEp.og_was_ servlet_engine1? pagerOffset=0\&maxPageItems=10\&maxIndexPages=10\&searchKey=\&searchValue= \&menuId=36\&boardId=41\&boardMasterId=2\&boardCategoryId= (accessed on 2 October 2018).

48. 2030 Road Map. Available online: http://2030ghg.or.kr/references/?mod=document\&uid=15 (accessed on 10 November 2018).

49. Malins, C. Driving Deforestation; Cerulogy and Rainforest Foundation: Oslo, Norway, 2018; Available online: https://d5i6is0eze552.cloudfront.net/documents/Publikasjoner/Andre-rapporter/Cerulogy_ Driving-deforestation_Jan2018.pdf?mtime=20180122234132 (accessed on 10 November 2018).

50. Tessum, C.; Hill, J.; Marshall, J. Life cycle air quality impacts of conventional and alternative light-duty transportation in the United States. Proc. Natl. Acad. Sci. USA 2014, 111, 18490-18495. [CrossRef]

(C) 2018 by the authors. Licensee MDPI, Basel, Switzerland. This article is an open access article distributed under the terms and conditions of the Creative Commons Attribution (CC BY) license (http://creativecommons.org/licenses/by/4.0/). 